DOI: 10.1515/ausp-2015-0019

\title{
The Complete Thesaurus of the Old Hungarian Language in Transylvania
}

\author{
Borbála ZSEMLYEI \\ Department of General and Hungarian Linguistics \\ Faculty of Letters, Babeş-Bolyai University \\ zsemlyei@yahoo.com
}

\begin{abstract}
The study deals with the Historical Dictionary of the Hungarian Language in Transylvania. It presents the process of its elaboration: the gathering of the data, the editing of the entry words and the orthography of the texts. It also presents the future perspectives and the philological relevance of the Dictionary.
\end{abstract}

Keywords: data gathering, historical dictionary, language distribution

\section{Introduction}

2014 is a historical date in the life of the Historical Dictionary of the Hungarian Language in Transylvania as after long decades of hard and sometimes even hopeless work its last ( $\left.14^{\text {th }}\right)$ volume appeared.

The thought of such a dictionary appeared in the 1920s, when the young Transylvanian linguist, Attila Szabó T., started gathering data for a dictionary of old Hungarian legal terms in Transylvania. In the autumn of 1925, he fell under the spell of research in archives as a student of the archivist Lajos Kelemen. Gradually, he developed a plan to use the gathered data for researching the vocabulary of the old Hungarian language spoken in Transylvania.

\section{The history of the dictionary. The man behind the dictionary}

The concept of editing a special dictionary which would cover the complete vocabulary of the Hungarian language used in Transylvania is closely linked to the linguist Attila Szabó T. (1906-1987). Besides being one of the most well-known Transylvanian linguists, he was also interested in ethnography, history and the 
history of literature. As far as linguistics is concerned, his main interests were onomastics, the Transylvanian dialects and historical toponymy. He started working at the university in 1940 and became head of the Linguitics Departament in 1945, when the Bolyai University was founded. However, in 1952, due to the political interests of the period, he was fired from the university and was transferred to the Linguistic Institute of the Romanian Academy, where he became a member of the team that edited a comprehensive Romanian-Hungarian dictionary. Not before two years, in 1952, was he allowed to return to the university where he worked continuously, without interruptions until his retirement in 1971, teaching historical linguistics. Some of his most important works are: Anyanyelvünk életéról (1970), A szó és az ember, Nyelv és múlt, Nyelv és irodalom (1981), Tallózás a múltban (1985), Közép-Szamos vidéki határnevek (1932), Kéziratos énekeskönyveink és verses kézirataink a XVI-XIX. században (1934), Miért és hogyan gyújtsünk helyneveket? (1938), A Marosvásárhelyi Sorok és a Marosvásárhelyi Glosszák (1973).

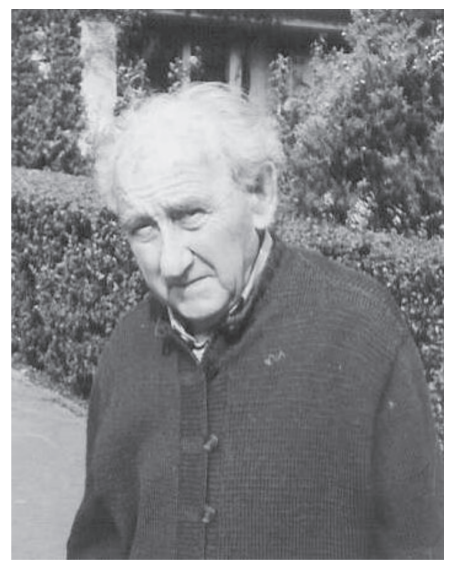

Attila Szabó T.

\section{The starting point of the dictionary}

In the 1920s, Attila Szabó T. - as a student of the archivist Lajos Kelemen - started gathering data in the archives throughout Transylvania for a dictionary that would present the old legal terms used in all kinds of legal processes in Transylvania. However, the more documents he analysed the more convinced he became that it would be a shame not to do anything with the language material contained by all those documents. So, at first, he wrote out on small paper cards words of old Hungarian used in Transylvania in a short context, and then he gradually developed a plan to use the gathered data for researching the vocabulary of the Hungarian language spoken in Transylvania. This was a very tedious and time-consuming job. 


\section{The Historical Dictionary of the Hungarian Language in Transylvania in some numbers}

The result of a century of hard work is the Historical Dictionary of the Hungarian Language in Transylvania, which gives a complete account of the Hungarian language of the period between the $15^{\text {th }}$ and the $19^{\text {th }}$ century of Transylvania in 14 volumes. The editors worked with about 1.5 million cards partly in the handwriting of Attila Szabó T., partly cut out from printed documents from the period mentioned above.

Whereas the birth of the idea of such a dictionary can be traced back to 1925, the first volume of the gigantic work appeared 50 (!) years later, in 1975. Attila Szabó T. was the single editor of the first volume, but soon he realized that the amount of work was so huge that it was impossible for a single person to do it. As a result, he formed a group of editors mainly from his co-workers at the Hungarian Language Department of the Babeş-Bolyai University. Until the publishing of the last volume in 2014, a total number of 23 editors worked on the dictionary. The 14 volumes contain around 16,500 printed pages.

\section{In what way is the Historical Dictionary different?}

The Historical Dictionary of the Hungarian Language in Transylvania is an unusual historical dictionary as it does not only contain written linguistic data, but it also reflects the spoken language (it was the policy of legal processes in the period between the $15^{\text {th }}$ and $19^{\text {th }}$ centuries that the witness accounts had to be registered precisely word by word, also mentioning the name, age, job and social status of the witness). Therefore, it provides great material for historical sociolinguistic and pragmatic research.

\section{The origin of the data}

The language material of the Historical Dictionary of the Hungarian Language in Transylvania comes from varied sources starting with the most informal texts up to the most formal ones, which is the reason why we can get a complete view on the old Hungarian language used in Transylvania. At first, Attila Szabó T. gathered only hand-written texts from the archives which were private and official letters, various inventories and bills, official registers of interrogations, the official orders of the prince of Transylvania etc. However, when he actually started editing the dictionary, he realized that the language material would not be complete without 
the most important printed texts of the period, such as memoirs, autobiographies and correspondences, for example Törökországi levelek by Kelemen Mikes, Metamorphosis Transylvaniae by Péter Apor, Önéletírás by Miklós Bethlen, A csíki vashámor a XVII. század második felében by József Pataki, the printed correspondences of Mihály Teleki and István Petelei, as well as the printed documentation of Katalin Varga's trial, Tót csipke, tót hímzés a XVIII. századi Erdélyben by Gertrúd Palotay, or the recipe book of Anna Bornemisza from 1680 etc. The earliest printed legislations are also to be found in the language material of the dictionary Compillatae Constitutiones Regni, which was published in 1671, and Approbatae Constitutiones Regni Transylvaniae, published in 1677.

The enumeration of the sources is far from complete, but this in itself shows the richness of the language data of the Historical Dictionary of the Hungarian Language in Transylvania. The richness and variety of the language material makes the dictionary a valuable study source not only for linguists but for researchers from other fields as well, such as historians, folklorists, and other researchers studying the history of natural sciences etc.

\section{The distribution of the language data in space and time}

When starting editing the dictionary, Attila Szabó T. considered it to be important to set a time frame for the language material to be contained by the dictionary. In the beginning he thought that the earliest time border should be the year when the Transylvanian Principate was founded, namely 1541, as this year was not only important in the political history of Transylvania, but also from then on the number of Hungarian written documents had increased dramatically. However, while conducting his research in the archives, he also found earlier language data. The earliest language data of the dictionary come from the end of the $14^{\text {th }}$ century, but there are a few toponyms and names from the $13^{\text {th }}$ century as well.

The geographical area is the territory of historical Transylvania: Partium, Kolozsvár and its surroundings, Dés; Torda-Aranyos; Szolnok-Doboka; Belső Szolnok; Kis Küküllő; Nagy Küküllő; Udvarhelyszék; Háromszék; Marosszék; Fogaras; and Alsó Fejér counties.

\section{The structure of the Historical Dictionary of the Hungarian Language in Transylvania}

Initially, Attila Szabó T. wanted to create the complete dictionary of old Hungarian in Transylvania, which - in his opinion - meant including as entry words not only 


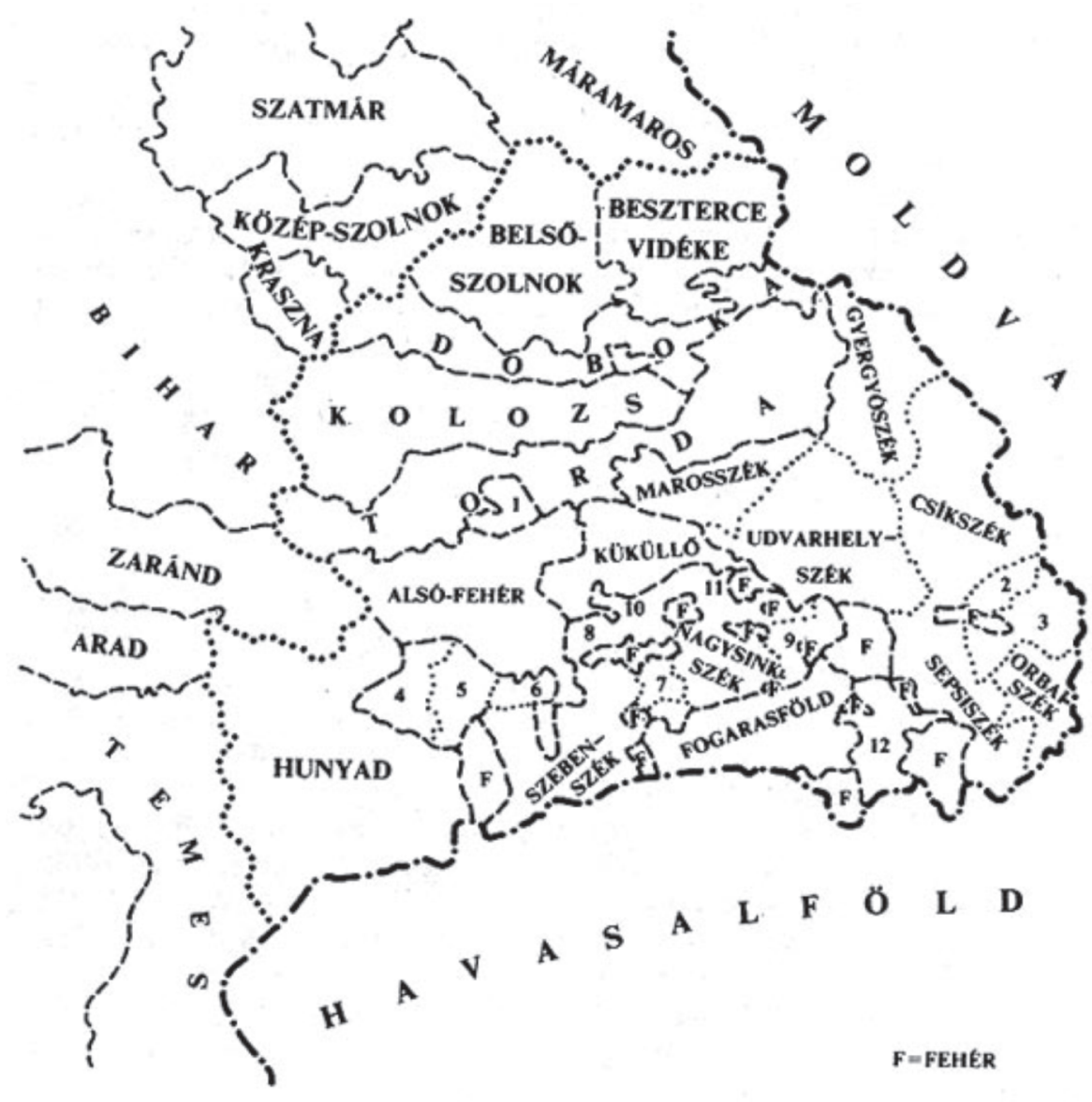

Map: the geographical distribution of the language data of the Historical Dictionary of the Hungarian Language in Transylvania

stem words and words with derivational suffixes, but also those with inflectional suffixes (e.g.: -ba, -be, -ban, -ben, -int, -képpen, -kor, -lag, -leg, -lan, -len, -szor, -szer, -ször). So, for instance, if we only take into consideration the lexical family of the word 'akadály', then there are the following entry words in the first volume of the dictionary: akadálykodik, akadályos, akadályoskodás, akadályoskodhatik, akadályoskodik, akadályoz, akadályozhat, akadályoztat, akadályoztatás, akadályoztathat, akadályoztatik, akadályoztató, akadályoztattatik.

It is also not common for dictionaries to contain as entry words tighter and looser word structures, but from a linguistic point of view this is very important as we can witness in time the way in which words generally used in each other's company in context became compounds (e.g.: egy-test-vér $\rightarrow$ testvér). 
Important expressions characteristic for Transylvanian life and culture were also included as entry words: mardzsinán juh 'sheep raised in transhumance', Mátyás király pohara 'cup decorated with the portrait of king Mathias'; Mátyás király barna pénze 'the bronze coin issued by king Mathias'.

As it was characteristic for the old language to have several phonological variants of the same word, sometimes it was difficult to decide which was the main variant; therefore, in this case, the editors included double entry words (e.g.: maradott, maradt; szócs, szúcs). Another peculiarity is that in some cases the old standard variant and the new standard variant are not the same, so in these instances always the old standard stays as entry word (e.g.: fejér instead of fehér or malozsa instead of mazsola).

Proper names (first names, names of animals and various toponyms) are not included as independent entry words, but are listed in chronological order under the common noun which they originate from.

\section{The ortography of the texts}

From a historical point of view, the orthography of the old texts is very important as there is not only a difference from one historical period to another but from one writer to the other as well. Attila Szabó T. always considered it important to copy the texts in their original orthography; therefore, this variety is reflected in the Historical Dictionary of the Hungarian Language in Transylvania. As the printing technique was not too developed when the first volumes appeared, Attila Szabó T. had to find a way in order to preserve the orthography, on the one hand, yet to use characters that could be printed, on the other. So, he found a way in which he was able to keep the original orthography, however he standardized the characters.

\section{The editing of entry words}

Apart from other traditional historical language dictionaries, the Historical Dictionary of the Hungarian Language in Transylvania presents the entry words in alphabetical order, thus allowing this language material to be easy to search and research. While editing the entry words, usually there are no grammatical references given in order not to burden the reader. However, when a word can be used in different contexts as different parts of speach, then these part of speech values are ennumerated under Roman numbers. For example, szakadatlan can have both adjectival ('continuous') and adverbial ('continuously') value; therefore, under I. texts that show the adjectival value are listed, whereas under II. are the texts that show its adverbial usage. 
One of the most important tasks of the editors is to determine the exact meaning(s) of the entry words. As the meanings are established based on the contexts in which these words are used, sometimes they have either more or completely different meanings compared to today's standard. The meanings are translated into Romanian and German, because together with Hungarian these three nations populated Transylvania, and in this way Romanian and German linguists and historians can use the data of the dictionary as well. Under each meaning, texts containing the entry word in the given meaning are listed in chronological order. Due to the fact that in the case of more common words there is a huge amount of language data, the editors have to decide which are the most relevant texts for (a specific meaning of) the entry word. The earliest and latest data are always included, and from each century the three most relevant texts. Apart from the chronological criteria, geographical considerations are also taken into account. That means that the language data are supposed to cover the entire area of Transylvania, thus making it possible for linguists to conduct a historical-dialectological research.

The entry words are often used in common phrases which are also included in alphabetical order under the main meaning they belong to, separated by a star sign. Following the common phrases, if there are, the sayings are listed as well. The personal names, animal names and toponyms are presented at the end of the entry word.

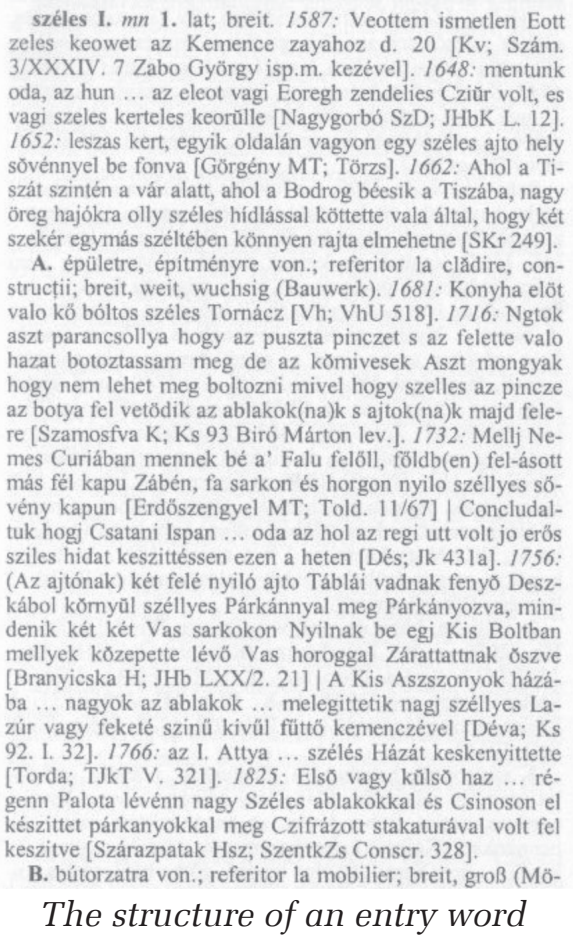

széles I. mn 1. lat; breit. 1587: Veottem ismetlen Eott zeles keowet az Kemence zayahoz d. 20 [Kv; Szám. oda, az hun .... az eleot vagi Eoregh zendelies Cziŭr volt, es vagi szeles kerteles keorũlle [Nagygorbó SzD; JHbK L. 12] 1652: leszas kert, egyik oldalán vagyon egy széles ajto hely öreg hajókra olly széles hídlással köttette vala által, hogy két szekér egymás széltében könnyen rajta elmehetne [SKr 249]. A. épuletre, épitményre von, referitor la cládire, constructii; breit, weit, wuchsig (Bauwerk). 1681: Konyha elöt kóltos széles Tornácz [Vh; VhU 518]. 1716: Ngtok hazat botoztassam meg de az kơmivesek Aszt mongyak hogy nem lehet meg boltozni mivel hogy szelles az pincze az botya fel vetödik az ablakok(na)k s ajtok(na)k majd felere [Szamosfva K; Ks 93 Biró Márton lev.]. 1732: Mellj Nemes Curiában mennek bé a' Falu felöll, fơldb(en) fel-ásott más fél kapu Zábén, fa sarkon és horgon nyilo széllyes sôtuk hogi Csatani Ispan sziles hidat keszittéssen ezen a heten [Dés; Jk 431a]. 1756. (Az ajtónak) két felé nyiló ajto Tablai vadnak fenyó Deszdenik két két Vas sarkokon Nyilnak be egj Kis Boltban mellyek kơzepette lévö Vas horoggal Zárattattnak ószve [Branyicska H; JHb LXX/2. 21] | A Kis Aszszonyok házába ... nagyok az ablakok ... melegittetik nagj széllyes Lazúr vagy feketé szinủ kivül füttö kemenczével [Déva; Ks 92. I. 32]. 1766: az I. Attya ... szélés Házát keskenyittette [Torda; TJkT V. 321]. 1825: Elso vagy kŭlsó haz ... régenn Palota lévénn nagy Széles ablakokkal és Csinoson el keszittet parkanyokkal meg Czifrazott stakaturával volt fel B. bútorzatra von.; referitor la mobilier; breit, groß (Mö-

The structure of an entry word 
While editing, the editors have a very difficult job because the text cards are already so old that sometimes the 'simple' fact of reading raises difficulties. The cards are rather small, and besides the text, on the top of the card, the possible entry words are listed, while on the bottom of it the precise source is indicated. After having dealt with the card in respect of an entry word, that entry word is crossed out - either horizontally, meaning that it was not included in the dictionary, or diagonally, meaning that it was included.
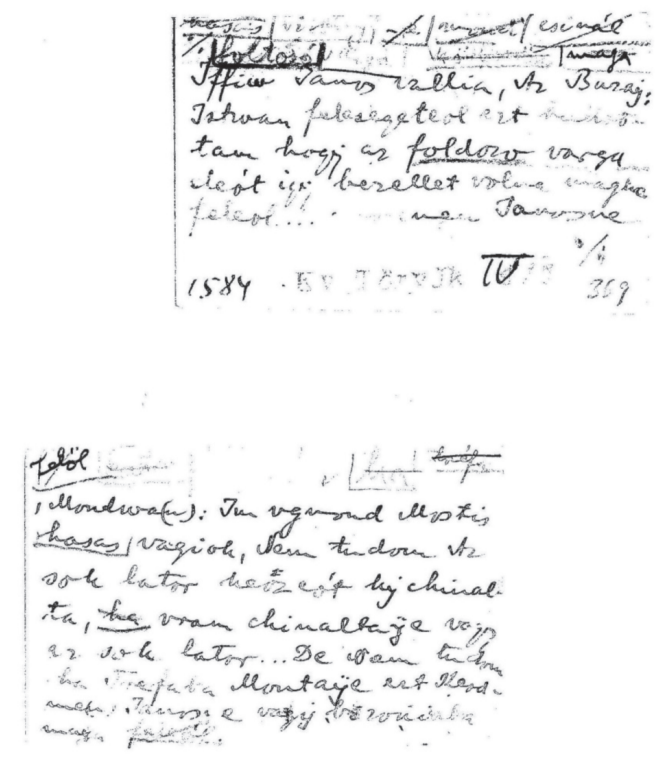

The raw material

\section{The people behind the Historical Dictionary of the Hungarian Language in Transylvania}

Attila Szabó T. envisioned the dictionary as a one-man work, but while editing the first volume (A-C), which appeared in 1975, he realized that it was phisically impossible for a human being to process the huge amount of language data that had been gathered throughout almost five decades. That is why he formed a team of editors from his closest co-workers at the Hungarian Language Departament of the Babeş-Bolyai University. Thus, the second volume (Cs-Elsz) was published in 1978 as a result of the joint effort of an editorial team formed by the following members: Ferenc Kósa, Jenő Nagy, Márta Vámszer, Károly Vigh and János Zsemlyei. The Romanian meanings were determined by Béla Kelemen, while the German ones by Jenő Nagy. From then on, there was a constant movement in the editorial 
team. Preparing the third volume (Elt-Fel), even though new members (Piroska B. Gergely and Mária Maksai Zs.) joined, lasted twice as long as the second one, and it was published only in 1982. The editing of the fourth volume (Fém-Ha) was completed in two years, having as new editors Erzsébet P. Dombi and Zsolt Szabó. After 1984, there was a long period of silence determined by the political ideologies of the age. However, the editors kept working, having their weekly meetings, even though there was absolutely no hope for the other volumes to appear. Not even the death of Attila Szabó T. in 1987 could stop them, and during about a decade's time, under the leadership of Márta Vámszer, they managed to prepare volumes V, VI and VII, which thus could be immediately published after the fall of the communist regime. The $5^{\text {th }}(\mathrm{He}-J \mathrm{u})$ and the $6^{\text {th }}$ volume $(\mathrm{K}-\mathrm{Ki})$ appeared in 1993 and the $7^{\text {th }}$ (Kl-Ly) in 1995. Even though it was such a hopeless period, the professor and later Márta Vámszer were able to recrute new members to the editorial team: Ágnes Dali, Miklós Kürty, Zsófia Seres and Judit W. Töröki. Unfortunately, there were some tragic losses as well: besides Attila Szabó T., two other members died: the editor Károly Vigh and the Romanian translator, Béla Kelemen. His job was taken over by Lőrinc Szász, who has been the Romanian translator ever since. The editor team was completed with Katalin P. Bodrogi and Magdolna K. Tichy at volume VI, and, starting volume VII, György Szabó joined, who was a specialist in classical philology. Yet, Zsófia Seres retired due to personal reasons. The $7^{\text {th }}$ volume (M-Meg) appeared in 1996 and had two new editors: Annamária M. Kabán and András Kiss, who has been the professional supervisor ever since the first volume and decided to do a little bit of editorial work in volume VIII. During the editing of volume IX (Megy-Op), Zsolt Szabó left the team, and, unfortunately, two collegues passed away: Mária Zs. Maksai and Jenő Nagy. That was the moment when the younger generation was also given a chance to work on the dictionary with the recruitment of Csilla T. Szabó. Emese Fazakas joined the editors in the preparation of volume X (Or-P), which appeared in 2000, while some of the German translations were done by Beáta DorkaFábián. For a short while, Edit Kádár also helped in the editorial work of volume XI (R-Száj), which appeared in 2002, but soon retired due to other professional activities, while Erzsébet P. Dombi left the team due to health problems. The German translations in this volume were done by Beáta Dorka-Fábián and Csilla Szabó. Unfortunately, the chief editor, Márta Vámszer did not live to see the volume being published. After the death of Márta Vámszer, the editing process of volume XII (Szák-Táv) was supervised by János Zsemlyei and Ferenc Kósa, but after the tragic death of János Zsemlyei, his work was taken over by Emese Fazakas. Fortunately, young collegues joined the team: Borbála Zsemlyei and Zselyke András. The $12^{\text {th }}$ volume was published in 2005. Beginning with volume XIII (Te-Var), the chief editor was Emese Fazakas, and she was able to prepare the dictionary to be published in 2009. The year 2014 is of historical significance in 
the life of the Historical Dictionary of the Hungarian Language in Transylvania, as the last volume (Vas-Zs) was published, having as chief editor Emese Fazakas and as editors: Piroska B. Gergely, Ferenc Kósa, Miklós Kürti, Csilla T. Szabó and Borbála Zsemlyei. The Romanian translations were done by Lőrinc Szász and the German ones by Beáta Jarosova and Júlia Volkán.

As a conclusion, it is important to emphasize that this monumental work is the joint team effort of more than 30 editors, who worked with all their conscience in order to make Attila Szabó T.’s dream come true.

\section{The future}

Although the monumental work, which is the Historical Dictionary of the Hungarian Language in Transylvania, has been completed, there are new tasks arising from the characteristics of our times. The editors want to make the dictionary available for researchers throughout the world to be able to use and research the valuable materials; therefore, the most urgent task is to digitalize the dictionary.

\section{References}

Fazakas, Emese. 2007. Az Erdélyi Magyar szótörténeti tár mint rendhagyó történeti lexikográfiai munka. In: Magay Tamás (ed.), Múlt és jövő vonzásában. Lexikográfiai Füzetek 3. Akadémiai Kiadó, Budapest. 23-36.

2014. Útmutató. In: Fazakas Emese (ed.), Erdélyi Magyar szótörténeti tár XIV. Erdélyi Múzeum-Egyesület, Kolozsvár. 8-12.

Szabó T., Atilla. 1969. Egy erdélyi szótörténeti tár szerkesztése közben. MNy 65. 403-17. 